\title{
A case of posterior reversible encephalopathy syndrome associated with sepsis
}

\author{
Orlando Garner, Ana Ramirez, Alfredo lardino
}

Department of Internal Medicine, Texas Tech University Health Science Center at Permian Basin, Odessa, Texas, USA

\section{Correspondence to}

Dr Alfredo lardino, alfredo.iardino@ttuhsc.edu

$\mathrm{OG}$ and $\mathrm{Al}$ contributed equally.

Accepted 26 June 2018

\section{SUMMARY}

Posterior reversible encephalopathy syndrome (PRES) is a neurological disorder characterised by parieto-occipital vasogenic oedema seen on MRI. Infection and sepsis has been reported as a possible cause for this disorder. We present a 19-year-old immunocompetent Caucasian man with known type 1 diabetes mellitus who presented to the emergency department with acute onset of bilateral visual loss, headaches and hypertension; he had been discharged 2 weeks ago for severe diabetic ketoacidosis and Staphylococcus aureus bacteraemia. Initial CT scan of the head was negative, but MRI showed findings suggestive of PRES. He was treated with nicardipine drip for strict blood pressure management and symptoms resolved within 4 days. PRES is a rare disease that has been increasingly reported as MRI becomes more commonplace. Usually associated with immunological disease, pre-eclampsia and cytotoxic therapies but an association with sepsis due to grampositive bacteria.

\section{BACKGROUND}

Posterior reversible encephalopathy syndrome (PRES) is a neurological disorder characterised by parieto-occipital vasogenic oedema seen on

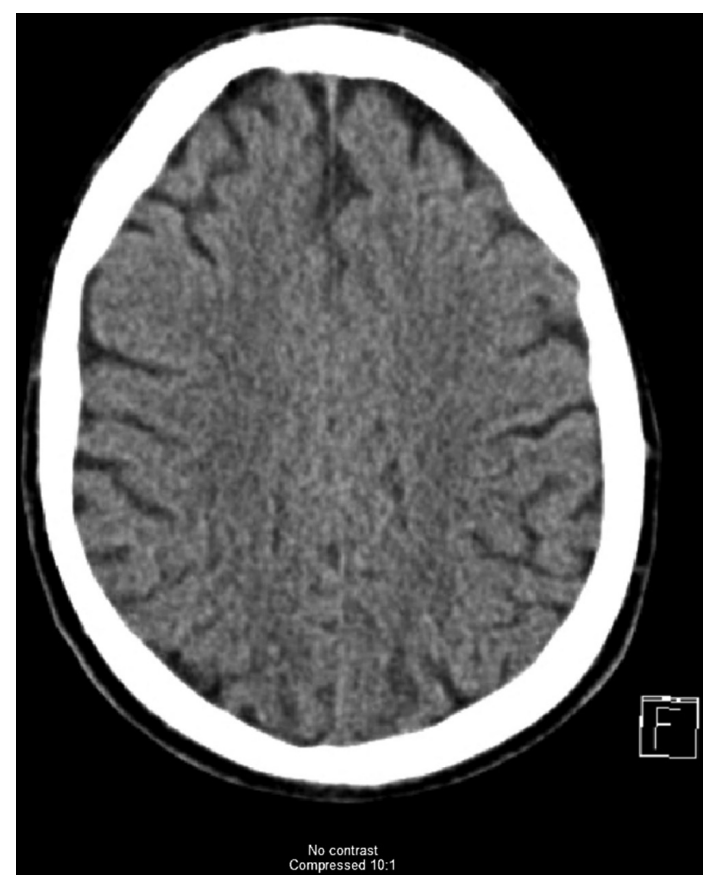

Figure 1 Head CT without any pathological findings at the same level that MRI (figure 2).
MRI. It encompasses a constellation of symptoms, including vision loss, headaches, seizures and elevated blood pressure. ${ }^{1}$ A myriad of conditions has been associated with it, including immunological diseases, pre-eclampsia, eclampsia, renal failure and cytotoxic drugs, but infection and sepsis has been reported as a possible cause for this disorder. ${ }^{2}$

\section{CASE PRESENTATION}

We present a case of a 19-year-old immunocompetent Caucasian man with known type 1 diabetes mellitus who presented to the emergency department with acute onset of bilateral visual loss and headaches; he had been discharged 2 weeks prior after a prolonged hospital stay due to severe diabetic ketoacidosis (DKA) and methicillin-sensitive $S$. aureus (MSSA). Physical examination revealed a diaphoretic young adult in apparent distress due to headache with blood pressure of $220 / 115 \mathrm{~mm} \mathrm{Hg}$, respiratory rate of 20 , heart rate of 105 , temperature of $36.9 \mathrm{C}$, no nuchal rigidity, pupils equal and reactive to light, bilateral basal crackles on chest auscultation, scrotal and pedal oedema, Glasgow Coma Scale 15/15. Laboratory data were remarkable for glucose of $257 \mathrm{mg} / \mathrm{dL}$. Cerebrospinal fluid disclosed white cell count of $5 \times 10^{\wedge} 9 / \mathrm{L}$, glucose of $66 \mathrm{mg} / \mathrm{dL}$ and protein of $31 \mathrm{mg} / \mathrm{dL}$. CT scan without contrast showed no acute intracranial pathological findings (figure 1). The patient had a generalised tonic-clonic seizure while awaiting MRI, the findings of which were consistent with PRES (figure 2). He was admitted to the intensive care unit with a nicardipine drip for strict blood pressure control and levetiracetam for seizure management. Symptoms resolved completely after 4 days of in-hospital treatment and he was discharged home on antihypertensive and anticonvulsant therapy with levetiracetam, with instructions to follow-up with neurologist in 3 weeks.

\section{INVESTIGATIONS}

- CT scan of head.

- MRI scan of brain.

- Blood cultures.

- Cerebrospinal fluid analysis.

\section{DIFFERENTIAL DIAGNOSIS}

- Multiple sclerosis.

- Acute disseminated encephalomyelitis.

- Human T cell leukaemia-lymphoma virus.

- Infectious encephalomyelitis. 


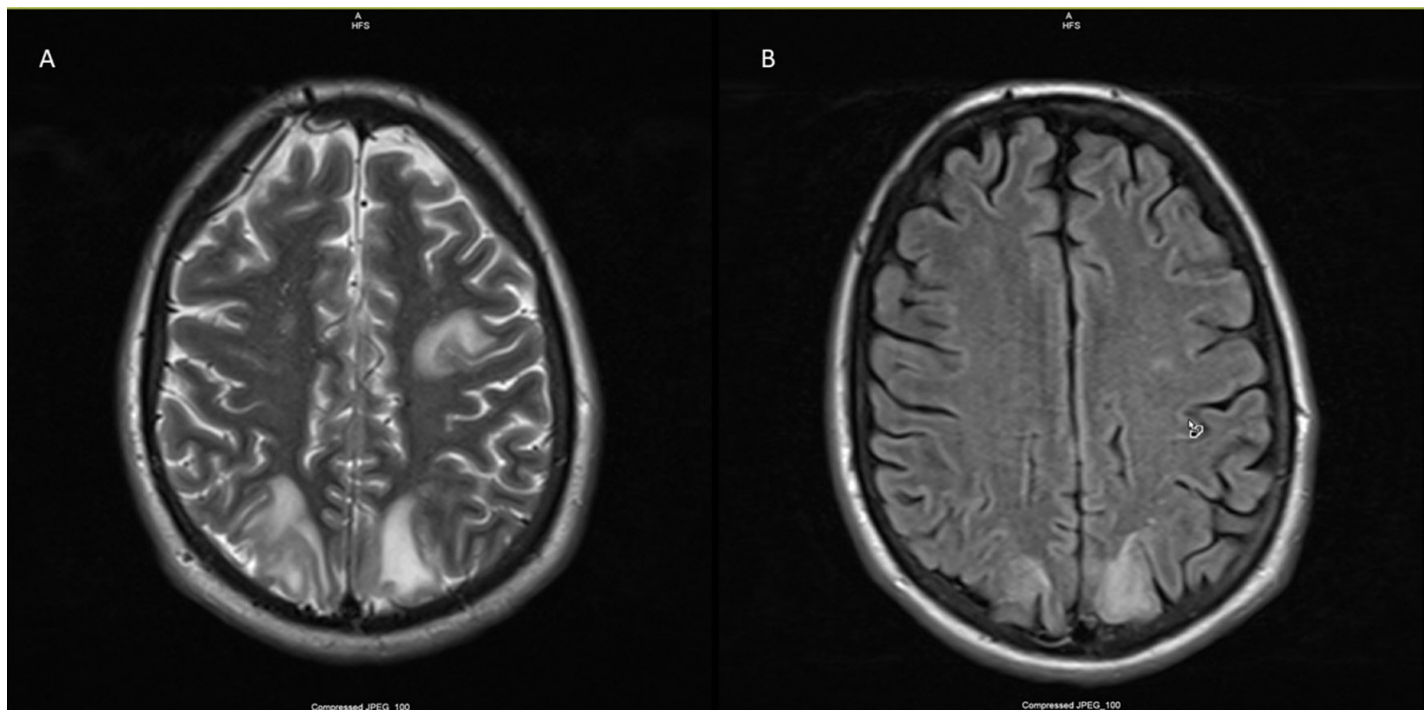

Figure 2 MRI of the brain with T2 (A)/flair (B) signal within the posterior aspects of the parietal and occipital lobes bilaterally compatible with posterior reversible encephalopathy syndrome.

- Autoimmune or paraneoplastic encephalomyelitis.

- Central nervous system vasculitis.

\section{TREATMENT}

- Nicardipine drip.

- Levetiracetam.

\section{OUTCOME AND FOLLOW-UP}

Patient's symptoms completely resolved, and was sucessfully discharged from the hospital with neurologist follow up.

\section{DISCUSSION}

PRES is a rare disease that has been increasingly reported as MRI becomes more commonplace. Usually, it is associated with immunological disease, pre-eclampsia and cytotoxic therapies but several case reports and a retrospective study done by Bartynski have demonstrated an association with sepsis, especially those caused by gram-positive bacteria. ${ }^{3}$ Our patient was admitted 2 weeks prior to the presentation with severe DKA complicated with septic shock due to MSSA bacteraemia. Most cases of PRES exhibit visual disturbances, headaches, seizures and hypertension, all of which were manifested by our patient. ${ }^{5}$ Diagnosis

\section{Learning points}

- Posterior reversible encephalopathy syndrome is a neurological disorder that causes vasogenic oedema diagnosed with MRI.

- It's usually associated to immunological disease, preeclampsia and cytotoxic therapies, but sepsis, especially with gram-positive bacteria, has been linked to the disease.

- There are no guidelines for treatment of this disease, but tight blood pressure and seizure control has been the mainstay of therapy. is made based on clinical presentation and MRI findings. ${ }^{6}$ The mainstay of treatment remains symptomatic with strict including blood pressure control and seizure prevention. ${ }^{78}$ Prognosis is good, with most patients having a full neurological recovery within days, without any significant sequelae. ${ }^{9}$

Acknowledgements Dr William R. Davis, Program Director of the Internal Medicine Program at Texas Tech University Health Science Center at Permian Basin for his invaluable help with the editing and proof read of this manuscript.

Contributors OG and AR: writing of manuscript, patient care, radiological review editing of images. Al: writing of manuscript, patient care, radiological review, editing of images. Final manuscript approval.

Funding The authors have not declared a specific grant for this research from any funding agency in the public, commercial or not-for-profit sectors.

Competing interests None declared.

Patient consent Obtained.

Provenance and peer review Not commissioned; externally peer reviewed.

\section{REFERENCES}

1 Roth C, Ferbert A. The posterior reversible encephalopathy syndrome: what's certain, what's new? Pract Neurol 2011;11:136-44.

2 Fischer M, Schmutzhard E. Posterior reversible encephalopathy syndrome. J Neurol 2017;264:1608-16

3 Fugate JE, Rabinstein AA. Posterior reversible encephalopathy syndrome: clinical and radiological manifestations, pathophysiology, and outstanding questions. Lancet Neurol 2015;14:914-25.

4 Bartynski WS, Boardman JF, Zeigler ZR, et al. Posterior reversible encephalopathy syndrome in infection, sepsis, and shock. AJNR Am J Neuroradiol 2006;27:2179-90.

5 Lee VH, Wijdicks EF, Manno EM, et al. Clinical spectrum of reversible posterior leukoencephalopathy syndrome. Arch Neurol 2008;65:205-10.

6 Covarrubias DJ, Luetmer PH, Campeau NG. Posterior reversible encephalopathy syndrome: prognostic utility of quantitative diffusion-weighted MR images. AJNR Am J Neuroradiol 2002;23:1038.

7 Stott VL, Hurrell MA, Anderson TJ. Reversible posterior leukoencephalopathy syndrome: a misnomer reviewed. Intern Med J 2005;35:83-90.

8 de Haro C, Ferrer R, Tercero A, et al. [Posterior reversible encephalopathy syndrome (pres) in sepsis]. Med Intensiva 2012;36:656-8.

9 Roth C, Ferbert A. Posterior reversible encephalopathy syndrome: long-term follow-up. J Neurol Neurosurg Psychiatry 2010;81:773-7. 
Copyright 2018 BMJ Publishing Group. All rights reserved. For permission to reuse any of this content visit http://group.bmj.com/group/rights-licensing/permissions.

BMJ Case Report Fellows may re-use this article for personal use and teaching without any further permission.

Become a Fellow of BMJ Case Reports today and you can:

- Submit as many cases as you like

- Enjoy fast sympathetic peer review and rapid publication of accepted articles

Access all the published articles

- Re-use any of the published material for personal use and teaching without further permission

For information on Institutional Fellowships contact consortiasales@bmjgroup.com

Visit casereports.bmj.com for more articles like this and to become a Fellow 